\title{
Overseas Filipino workers in conflict zones: narratives of Filipino nurses in Libya
}

\author{
Ron Bridget T. Vilog ${ }^{1 *}$ and Marie Donna M. Ballesteros ${ }^{2}$
}

\author{
${ }^{*}$ Correspondence: \\ ron.vilog@dlsu.edu.ph \\ 1 International Studies \\ Department, De La Salle \\ University-Manila, Manila, \\ Philippines \\ Full list of author information \\ is available at the end of the \\ article
}

\begin{abstract}
This paper examines the risk perception of Filipino nurses who worked in Libya during the height of post-2011 crisis. The narratives reveal that Filipino nurses took advantage of the massive hiring campaign organized by Libya's Ministry of Health in 2012, hoping that their migration experiences would result in economic and social rewards as they established their careers in the healthcare industry. After 2 years of adjustment to the conflict-ridden environment, they found themselves situated in another episode of civil war, once again defying the Philippine government's mandatory repatriation program. Guided by Carretero's (Risk-taking in unauthorised migration, 2008) thesis, we observed the mechanism of defiance that entails risk-taking as the political crisis loomed. Filipino nurses, especially those who initially refused to leave Libya, embraced an "illusion of control" that eventually reinforced an "unrealistic optimism."These risk-minimizing strategies have successfully undermined the protective powers of the state. The paper argues that Filipino migrants in crisis zones like Libya undertake risk calculation and reduction, albeit with a tendency to commit risk denial and a false sense of empowerment and exceptionality. In the end, however, it is emphasized that these mechanisms have limitations, depending on the experiences, timing, and risk interpretation of the migrants.
\end{abstract}

Keywords: Filipino nurses, Migration, Conflict zones, Repatriation, Libya

\section{Background}

The literature on migration and development has often emphasized the case of the Filipino diaspora in establishing transnational communities and forging nationalism beyond territoriality. Migration scholars and students of the social sciences have thoroughly examined the dynamics of Filipino migration because of its striking attributes: First, since the 1970s, the Philippine government designed the marketability and facilitated the overseas deployment of workers. Second, the Philippines assumes a substantial role for its deployed citizenry. Thus, this migration system has developed a transnationalized citizenship, which served as an agent of the state to discipline migrants as flexible labor (Rodriguez 2002). Third, as a result of the state's institutionalization of migration, the Filipino society has deeply developed a "culture of migration," as evident in households from the lower to the upper echelons of the social structure.

The case of Filipino nurses exemplifies this. The Philippines takes pride in deploying globally competitive nurses who are currently manning medical facilities and

(c) 2015 Vilog and Ballesteros. This article is distributed under the terms of the Creative Commons Attribution 4.0 International License (http://creativecommons.org/licenses/by/4.0/), which permits unrestricted use, distribution, and reproduction in any medium, provided you give appropriate credit to the original author(s) and the source, provide a link to the Creative Commons license, and indicate if changes were made. 
community health centers around the world. For the past decades, the government has strictly maintained the standards of nursing education, training, and practice to ensure the global competitiveness of these health workers who are mostly lured for overseas deployment. As a consequence of the government's strategy in participating in the global trade of nurses, the Philippine healthcare industry has suffered from the exodus of competent health practitioners especially in rural areas. This migration system has created a "divergent development" worsened by the weakening of the rights of nurses (Ball 2004).

Because of these migratory trends, there is a rich pool of scholarly works on the dynamics of overseas Filipino migration, particularly on their plights, unique experiences, and conditions in the United States, Europe, Canada, and East and Southeast Asia (Choy 2003; Ball and Piper 2002; David 1991; Espiritu 2003; Fresnoza-Flot 2009; Stasiulis and Bakan 1997; Tacoli 1999). Such studies reverberate with the conventional pattern of labor migration from a poor, cheap labor, and opportunity-scarce local community to an ideal destination: a place with relatively high paying job opportunities, citizenship/residency options that provide adequate social safety nets, and reliable security. The cases discussed here diverge from this pattern on one important point-the destination country can no longer guarantee security.

As "new trends and patterns" of labor migration from the Philippines are explored, it is also important to understand the path taken by those who chose a different destination. Inimical to the neoclassical perspective, it poses contention and raises questions as to how and why this migration occurs. Supplementing what is known about the welldocumented narratives of disempowerment and survival in the US and Saudi Arabia, this paper sheds light on the other dimension of migrant vulnerability, highlighting the various ways that they cope in a conflict zone and exposing the nuances of protecting Filipino migrants in high-risk environments.

Of particular interest is the movement of nurses to Libya, a country in transition from civil war in 2011 and that has since been beset by recurring violence, with infiltrations from the Jihadist militant group, ISIS. What motivates the Filipino nurses to take the risk of migrating to a conflict zone like Libya? What factors sustain this system of migration to a place of uncertainty and war? It is indeed curious why more than 4000 Filipinos still remain in Libya amidst the declaration of Crisis Alert Level 4, which imposes mandatory repatriation. The analysis employs risk frameworks, particularly Carretero's (2008) notion of "unrealistic optimism" in explaining the dynamics of migration, the initial failure of repatriation, and the limitations of risk minimizing strategies.

\section{Methodology}

This study utilizes qualitative approaches in collecting and analyzing life stories of Filipino nurses from Libya. Life history interviews, with an emphasis on pre-migration perspectives, migration experiences, and post-migration insights were conducted using semi-structured questionnaire from January to May 2015. The interviewees are Filipino Registered Nurses (RN) who have experienced living and working in Libya right after the civil war in 2011. As an exploratory study, this research highlights the narratives of eight Filipino nurses who have worked in Libya's medical institutions from 2012 to 2014. The interviewees were recruited through a snowball sampling technique, which was initiated through social media. The research participants, including 6 male and 2 female 
nurses, with an average age of 29, came from various areas in the Philippines: Cavite, Samar, Romblon, Zamboanga, Manila, and Quezon City. All interviewees are single, but describe themselves as "breadwinners" upon assuming great responsibilities in supporting their parents and siblings. In addition, data from the Philippine government and migrant NGOs are also analyzed. Media clippings and other secondary sources have likewise been helpful in understanding the events and contextualizing the narratives based on the conflict scenario.

The discussion begins by laying down the trends and patterns of Filipino migration as the backdrop of nurse migration. We then describe the destination country, Libya, and characterize its labor and health sector. Having laid down the general context, we examine the narratives of Filipino nurse migrants in Libya.

\section{Trends and patterns of Filipino migration}

The dominant theories of migration underscore the tendency of people to seek destinations that offer good economic opportunities, vast land and resources, and upright political freedoms. Neoclassical theory, for instance, predicts that migrants take the path of migratory movement from the least developed countries to the richest countries. This perspective also suggests that migrants have perfect knowledge of the salary and economic opportunities in the destination place (Castles and Miller 2009). This model of migration has been demonstrated by most Overseas Filipino Workers (OFWs) who left their home communities to work in developed countries where compensation packages are comparatively better than the salaries offered in their home country. Based on the 2012 Estimate Stock of Overseas Filipinos, the top 10 countries of destination of OFWs include Australia, the US, Saudi Arabia, Canada, Malaysia, the UAE, Japan, Kuwait, the UK, and Qatar, all of which are considered as developed countries. The relatively higher wages in these countries have attracted both skilled and non-skilled Filipinos, thereby intensifying the migration flow. With the popularity of international migration, it is now recognized by various employment agencies in the Philippines that there has been an excess supply of workers; hence noting that "the market for overseas contract labor is a buyer's market" (McKenzie et al. 2014).

On the individual level, OFWs tend to maximize the economic benefits of migration, although the risks and benefits may not be equal between men and women. Filipino men and women tend to migrate to different destinations where the demand for their gender group would be higher, and would allow them to take on different jobs (Semyonov and Gorodseisky 2005). It was also noted that men send more remittances because the average earning of women is lower than men. As to the risks, migrant women were found to be more vulnerable because of their concentration in domestic services and entertainment (Asis 2002). While there are significant changes and development in terms of gendered migration, the Philippine Commission on Women is still apprehensive on migration trends and policies by citing the Philippine Labor and Employment Plan 2011-2016 which mentions that "more than $60 \%$ of annual deployments of new hires over the past 9 years have been women; most of them work as caregivers and domestic workers in the Middle East, Hong Kong, Singapore, and Italy. Among high-skilled workers, Filipino nurses are also in great demand worldwide" (Philippine Commission on Women 2014). 
Recent trends have also revealed the changing contours of labor migration from the Philippines. More diversified in terms of occupation and level of skills, Filipino migrants have also changed their paths and patterns in the past years. The country report of IOM in 2013 mentions some of the most important trends recently exposed by migration data: First, most of the overseas workers come from the National Capital Region, Central Luzon, and Calabarzon. However, it appears that the places of origin have also diversified recently. Second, the destination countries went beyond the Gulf. OFWs have penetrated the foreign labor market in East and Southeast Asia, and the rest of the world. Finally, the occupational profile of OFWs includes various categories, from the less skilled to the professionals. However, because of the demand factors, majority of the Filipino labor migrants are engaging in less skilled occupation (IOM 2013).

As a labor exporting country, the Philippines has been significantly benefitting from migration. San Juan (2001) posits that the annual remittance sent by overseas workers have kept the country's economy afloat and "support the luxury and privileges of less than one percent of the people; the Filipino oligarchy." Aside from remittances, migrants also contribute to economic growth through entrepreneurial activities managed by the migrants' families in their home communities (Basa 2008). Also, this state sponsored migration has sustained the flow of diaspora philanthropy which appears to contribute to nation-building (Duaqui 2013). Recognizing their role in nourishing economic and social development, the government has glorified them as the bagong bayani (new heroes) of the nation.

With its state-led programs that facilitate recruitment and deployment overseas, the Philippines has become an agent of labor mobility that seemingly sells its people to prospective employers overseas. In the words of Rodriguez (2010), the state has become an active "broker" that offers labor to the world. When President Ferdinand Marcos launched the overseas program in the 1970s, it was intended to be a temporary measure to relieve domestic unemployment and balance-of-payments problem. At present, the government has already acknowledged the structural role of international labor migration to the overall development scheme. It has indeed regarded migration as part of globalization that can benefit the country's ailing economy (De Asis and Baggio 2008). The Philippine government has been involved in forging agreements with other states to penetrate the international labor market and to ensure that prospective migrants have job opportunities abroad. At the same time, the state has also taken the role of ensuring the protection of labor migrants by passing legislations that promote their welfare and security. Laws such as the Migrant Workers and Overseas Filipinos Act of 1995 (Republic Act 8042) and the Anti-Trafficking in Persons Act of 2003 (Republic Act 9208), for instance, have increased the role of the government in overseeing the activities and labor conditions of Filipinos outside the boundaries of the nation-state.

The Philippine government has reinforced its migratory controls by facilitating repatriation in areas where conflict and wars escalate. The Magna Carta for Migrant Workers allocates financial resources for emergency repatriation when the need arises. Section 15 of Republic Act 8042 specifically mandates the Overseas Workers Welfare Administration (OWWA), in coordination with appropriate international agencies "to undertake the repatriation of workers in cases of war, epidemic, disasters or calamities, natural and 
man-made, and other similar events." OWWA also supervises the emergency repatriation fund, which should initially consist of one hundred million pesos.

The Philippine government's experiences of repatriating its workers have earned some praises but mostly criticisms from civil society, media and international agencies. The largest repatriation to date occurred during the Gulf War in 1990-1991 wherein almost 30,000 Filipinos were repatriated from Kuwait (including some from Iraq). In 2006, another conflict in Lebanon called for a massive repatriation of 6000 OFWs, mostly women (IOM 2013). Most recently, the repatriation efforts caused by the Arab Spring specifically in Libya and Syria have posed another challenge to implement the repatriation mechanisms that admittedly disrupted the employment of thousands of Filipino workers. According to the 2013 Country Report of IOM, the Philippine Government considers the repatriation program from Libya as a successful campaign because of the good coordination between the Philippine government and the OFW's employers and recruitment agencies in rescuing and transporting the workers. This is in contrast to the repatriation experience in Syria where rescue operations proceeded "slowly and in a protracted manner." The operation became enormously challenging because most of the female OFWs in the area were irregular migrants.

In spite of the legal measures, bilateral agreements, and government-led programs for the migrants, OFWs remain vulnerable to institutional and societal injustices in their host countries. Undeniably, the national policy of the Philippine government has its weaknesses and shortcomings in terms of its design, implementation and reach considering that the missions abroad usually focus on diplomatic and other services (Battistella 2012). While OFWs are generally commended for their hard work and sacrifices, various problems emerging from the employment system and social adjustment pose great challenges not only to them and their respective families, but to the Philippine government as well. Aside from the usual experience of discrimination, many OFWs have been abused, exploited, and maltreated by their employers. Take the case of the domestic worker, Flor Contemplation, whose situation drew attention to the ghastly and dreadful side of labor migration. Her execution in Singapore on March 17, 1995 sparked public outrage because of the failure of the Philippine government to prevent the Singaporean government from imposing capital punishment. Since then, the public has questioned the ability of the government in protecting its overseas citizens.

In April 2015, another Filipino migrant has caught the attention of the public as she faced capital punishment in Indonesia. Mary Jane Veloso, a former domestic worker in Dubai, has been accused of smuggling $2.6 \mathrm{~kg}$ of heroine, prompting the Indonesian government to schedule her execution by firing squad together with eight other convicts. Prior to the scheduled execution, migrant workers' associations in the Philippines and Indonesia, buttressed by a vocal public, exerted a tremendous pressure on the Indonesian government to defer the execution. These efforts from civil society organizations and the public through social media, backed by diplomatic efforts of the Philippine government, have resulted in the issuance of a temporary reprieve. This event brought back the discourse of migrant victimhood and oppression into the public sphere. The government's policies on the exportation of overseas labor have once again faced severe criticism for its inability to protect overseas migrant workers. 
By the beginning of the 21st century, a new trend in labor migration emerged-not one dominated by domestic workers, no longer by engineers for the petroleum industry of the Middle East, but a more diverse group of migrants. A significant number of them are Filipino nurses, whose stories of migration rarely reached the heart-wrenching plight of the domestic workers.

\section{Migration of Filipino nurses}

According to Carlos and Sato (2008), the Philippines is one of the biggest exporters of nurses in the world. The country has responded well to international demands, albeit the "selective nature of nursing migration." The top three countries of destination for Filipino nurses for the last decade include Saudi Arabia, the USA, and the UK. Other preferred destinations include Libya, the United Arab Emirates, Ireland, Singapore, Kuwait, Qatar, and Brunei (POEA 2003). This was driven by a shortage of nurses in some western and Middle Eastern countries, also a consequence of an ageing population that raises the demand for health care and high rates of burnout and turnover among local nurses. These led several countries to be open to hiring health workers from developing countries.

The increasing success stories of Filipino nurses employed abroad also contributed to the profession's popularity. Inevitably, this also led to an oversupply of nurses and tough competition, as well as health institutions taking advantage of the situation by offering lower salaries. Some nurses even pay institutions to be accepted as interns, while some offer their services as volunteers, providing them the necessary training needed to qualify for employment abroad. Aside from the lure of better opportunities outside the country, nurses also look at the relative disadvantages of staying. Lorenzo et al. (2007) cited these common reasons for migration of Filipino nurses: economic (low salary, no overtime, poor health insurance coverage), job related (work overload or stressful working environment), and socio-political and economic environment (limited opportunities for employment, decreasing health budget, political instability).

Seizing such opportunities, Filipino students began taking up BS Nursing as an undergraduate degree. Some families have spent large amounts of money as investment for the future of their children, with the hope that after graduation, the rewards could be reaped in terms of higher income, more benefits, and eventually obtain citizenship in other countries. Consequently, nursing degrees not only became very popular, but have also grown more competitive, especially for university-based institutes. However, its popularity has also led to the mushrooming of low-quality but expensive nursing education. When the demand for nurses declined in 2007-2008, however, the oversupply of nurses became evident. After its peak in 2006-2007, enrollment figures were in gradual decline until 2010-2011 (Arends-Kuenning et al. 2015).

During the pre-migration stage, what is apparent to a would-be OFW are the relative disadvantages of staying in one's home country. The destination country and the assumed opportunities remain the "greener grasses" on the other side that, while yet to be explored, could spell a huge difference if the stories of successful OFWs would be the basis. In the case of a lesser known destination such as Libya, however, to what extent would the assumed better opportunities be true? 


\section{Libya as a magnet for labor migrants}

Libya is among the more prosperous countries in Africa, owing to its hydrocarbons industry that contributes $70 \%$ of its entire GDP. The same industry is the biggest source of government revenues at $94 \%$, (Abuhadra and Ajaali 2014). With income from hydrocarbons, Libya was able to finance its infrastructure and agriculture, allowing it to afford social welfare programs and in turn, makes it a favorable destination country to labor migrants from Sub-Saharan African and the neighboring Arab countries seeking better employment opportunities.

Under the leadership of its dictator Muammar Gaddafi, the country deliberately opened up the labor market, first, to the neighboring Arab countries. When the country failed to get the support of Arab countries during the air and arms embargo in 1992, preferential treatment was instead directed to Sub-Saharan countries in a policy of Pan Africanism. Nationals of other countries were likewise welcomed, but only for the citizens of states with which Libya had diplomatic ties. This open-door policy, coupled with having conflict-prone and underdeveloped neighboring countries, made Libya a destination of choice for both foreign workers and refugees.

Over time, however, labor migrants from neighboring countries began to view Libya no longer as a destination country but as a transit country through which they could have an opportunity to reach Europe by crossing the Mediterranean Sea to southern Italy. The commonly cited reasons for this phenomenon pertain to difficulties within the country. Facing international isolation in the 1990s, socio-economic conditions declined as the government's capacity to absorb foreign workers for manual job declined. As the number of both foreign workers and refugees increased, the relationship between locals and migrants, mostly against African migrants, turned sour. A growing atmosphere of hostility against foreigners arose, with the locals blaming the migrants for rise in criminality and spread of diseases, among others (Hamood 2006).

It was the concern over the influx of irregular migrants that increased Libya's cooperation with Europe, specifically with Italy. In view of this political consideration as well as its labor market condition, Libya initiated expulsions of foreign workers. Expulsions numbered from 4000 in 2000 to as high as 84,000 workers in 2005. In 2007, it began to impose a visa requirement to all foreign workers (Migration Policy Center Team 2013).

In 2011, a series of protest actions now known as the Arab Spring started in Tunisia, spreading over to Egypt, Lebanon, Jordan, and Yemen. Demands for democratic reforms spread over to Libya. Soon, activists in Libya began to rally against the Gaddafi regime as well, which the government dealt with violently. This attracted international attention. With the support of NATO, the rebels succeeded in taking over the country, ending with the death of Gaddafi, Libya's ruler for 40 years. The civil war caused a migration crisis where about 768,372 (31\% of migrants were estimated by the International Organization for Migration to have left the country out of the 1.2 million foreign workers recorded before 2011 (Migration Policy Center Team 2013). In the post-conflict period under the National Transition Council of Libya, hopes were held that conditions will improve, but the country slipped to violence again, with the takeover of oil facilities by rebel groups and infiltration of ISIS in some regions of the country.

The Libyan labor market has to bear the consequences of being a former socialist and post-conflict society after 2011 . As a former socialist state, the public sector looms large 
over all other sectors. World Bank data in 2011 revealed that $55 \%$ of the labor force was employed by the government through its education and healthcare sector, despite contributing merely $9 \%$ to the gross domestic product. These government employees receive high salaries and benefits, making it a highly coveted employment, at the cost of declining interest in private sector employment and a negative view of manual labor. So wide was the disparity between government and private employment in terms of income and benefits that when employed by the private sector, workers consider themselves unemployed (Abuhadra and Ajaali 2014).

As a post-conflict society, competing claims between the transitional government and the rebels over the operation and income of the hydrocarbons added instability to the economy. Furthering the post-conflict agenda, there is also a need to reintegrate former combatants and give them suitable employment. Another concern related to competing claims to power is the increasing informal sector. Amidst the political and economic crisis that Libya is experiencing, where do the OFWs stand?

\section{Filling the gaps: OFWs in Libya}

The Philippines and Libya entered into a bilateral agreement in 1979, opening the door to Filipino employment in the country in the areas of maritime, healthcare, agriculture and fisheries, operation and maintenance of infrastructure facilities, sewer and water systems, and urban and rural planning and development. ${ }^{1}$ At the expiration of the agreement in 2002, the two countries entered into agreement again in 2006, this time leaning towards OFWs' entry to the medical professions and construction. ${ }^{2}$

According to the data by Philippine Overseas Employment Administration, there were 34,591 OFWs deployed from 1993 to 2010. Of this, health-related workers constitute an average of $12.56 \%$ spread over the same period. In terms of remittances, the Central Bank of the Philippines recorded a total of US\$253 million from 1989 to 2014 with a steady rise from 2004 to 2010 but significantly dropping in 2011, owing to the Libyan crisis that year.

Compared with other foreign migrants in Libya, the OFWs seemed to be untouched by the ebb and tide of migration policy until the crisis in 2010. A closer look at the deployment data by the Philippine Overseas Employment Administration (POEA) from 1993 to 2011 shows that the expulsion of foreign workers in 1995, the devaluation of the Dinar in 2002 that made its local firms more competitive, and the expiration of the bilateral agreement between the Philippines and Libya, did not seem to affect the number of deployments to Libya. The 2006 bilateral agreement even came ahead of the Decree number 6 of 2007 opening the oil and healthcare industry to foreign workers. From 1246 deployments in 2007, the POEA recorded 4435 in 2011. As to the number of OFWs in Libya, the International Organization for Migration estimates reached 26,000.

Filipino nurses are employed in government-run health clinics and hospitals that are wellequipped to provide comprehensive healthcare to all citizens. With the government as their employer, they enjoy the privileges of receiving a high income and other allowances. During the 2011 civil war, however, these benefits began to be weighed against the increasingly

\footnotetext{
${ }^{1}$ Agenda for Cooperation in the Field of Labour, Employment and Manpower Development between the Republic of the Philippines and the Socialist People's Libyan Arab Jamahiriya.

2 Memorandum of Understanding Between the Government of the Republic of the Philippines and the Great Socialist People's Libyan Arab Jamahiriya.
} 
unstable security situation. The government called for repatriation during the crisis in 2011, and has renewed the call from Alert level 1 (precautionary phase) in May 2014 to 4 (total deployment ban and mandatory repatriation) in July of the same year. At the time of writing, the Philippines' Department of Foreign Affairs already repatriated a total of 4830 OFWs from Libya (GMA News 2015). The call is relentless, but the low number of people evacuating per batch, as well as the difference between those who register for repatriation and those who actually do has become a cause of concern (Santos 2014). In view of the worsening security situation in Libya, what is behind this ambivalence? What are the factors that prevent Filipino nurses from considering homecoming as the better option?

\section{Migrant stories: challenges from migration to repatriation}

This section discusses the migrant narratives of eight Filipino nurses who were repatriated from Libya. While the interviews covered the entire migration cycle of the respondents, the discussion is narrowed down to three important factors that affect the decision of Filipino nurses to repatriate or not in the face of security crisis in Libya: (1) pre-migration perceptions, (2) labor conditions, and (3) repatriation challenges.

\section{Pre-migration: motivations, opportunities, and risk perceptions}

Similar to the cases of other international labor migrants, Filipino nurses were initially attracted to higher salaries and benefits. A starting salary of 1200 Libyan dinar (US\$1260) was more enticing than the 7000 Philippine pesos (US\$157) that they can earn in the provinces or rural areas in the Philippines. Although Philippine legislators attempted to increase the salaries of Filipino nurses by upgrading their salary grade to level 15 (Php25,000 or US\$563), the offer from Libya is still incomparable to the compensation packages provided by renowned medical institutions in the Philippines.

At first, they were hesitant to work in Libya. All the interviewees intended to seek job opportunities in developed countries such as the US, Canada, the UK, Australia, or other well-known migrant destinations in the Middle East. However, the requirements and sluggish processing period discouraged them from pursuing that dream. Advertisements and invitations posted by Libya's Ministry of Health, channeled through several recruitment offices in the Philippines, paved the alternative path for them, with the relative ease of getting hired. Nelson, one of those who took advantage of the Libyan Ministry of Health's "massive hiring" in 2012, claimed that he was hired "in just 1 week." Another interviewee, Diana, was also surprised at the prompt processing of her documents:

The processing of our papers and visa was really fast, even faster than the application processing of those who applied for Saudi Arabia. Most importantly, the compensation package was better than the offer for Saudi Arabia.

Edward explained the ease and lenience of requirements in the hiring process for nurses:

I was trying to apply in other parts of the Middle East like Saudi, Qatar, and Oman but they have several considerations for hiring: the bed capacity of the hospital where you worked, the trainings that you attended and passed, etc. For Libya, there was no examination, no required training. During that time, they really needed nurses, so they initiated mass hiring. 
Prior to departure, the interviewees were all aware of the conflict situation in Libya. However, they have been assured by their respective recruitment agents and representatives from Libya that the situation has improved and the workplaces were safe. That assurance, corroborated by the support from the Philippine government, has lessened the perception of risk:

I trust that the Philippine government would not deploy its citizens to unsafe places. They wouldn't allow us to leave if there are problems [of security] in Libya. (Nelson).

James was also optimistic about the peace and order situation in Libya. He recalls:

We knew that there was war...but also, we knew that the dictatorship of Muammar Gaddafi has come to an end. So we thought it was okay to go there because there was no more dictator. We didn't think about the eventuality that the supporters and the opposing group would spark another civil war. Then came the ISIS. We didn't anticipate that.

Diane, meanwhile, summed up what she knew about Libya before going:

What I knew about Libya was that it's a rich country and it is in North Africa. And also one of the countries that got famous due to the recent unrest.

Lacking a deep understanding of the situations in the destination country, the risk perception of the interviewees was anchored on the assurances provided by the recruiting agents and the Ministry of Libya. They were also aware that government-led repatriation is possible when the situation gets worse. Agents and institutions were apparently trusted, effectively reinforcing the migration of nurses by guaranteeing the financial and physical security of health workers to a well-known conflict zone.

The assumption of a post-war yet violence-free destination prior to migration was confirmed when, upon arrival in 2012 and 2013, they found Libya to be, in the words of Nelson, "peaceful." Some nurses also felt secure because of the distance of their workplace from the main cities and conflict zones of Libya. Bombings, according to Nelson, only sparked in the early part of 2014. Edward's observation is worth noting:

It was like an apocalypse. You wouldn't see crowded areas. We saw broken (burned)

houses. We saw groups of militia and several armed groups. But when we got there, despite the presence of militia, it was peaceful.

Uncertain of what lies ahead of them in this new place, "peaceful" must have come as an assurance that all would be well, unaware of the socio-political undercurrents that might spark the violence anew.

\section{Labor conditions}

All the interviewees are in a consensus that they had a good start. The fascination of working abroad and the benefits that came with it gave the initial boost. Accommodation close to their workplaces was provided either for free or with a housing allowance, without any electricity or water bill to pay for. Some were given furniture allowance and individual allowances equivalent to a month's salary due to delay of the initial monthly 
salary. And when the entire compensation was given for an entire 6 months, Edward recalls his amazement:

Oh my God, it was a huge amount! It was my first time to have that amount of money. How would I spend it? So we bought all the things that we wanted to buy. I bought a tricycle for my father. I bought a cellphone for myself. The rest, I sent it for the education of my siblings.

The sudden improvement in financial capacity, contrasted with the financial worries that they had back home, was a relief. While there were some complaints about limited benefits, there was a general satisfaction in their initial stay.

An added comfort was the relative affluence of the country that facilitated their work. If health facilities and equipment alone were to be considered, Libya exemplified the advancement that the interviewees could only wish the Philippine healthcare institutions also had. Having experienced working in local hospitals or clinics back home, this difference is highlighted as something positive about the experience of working in Libya. Nelson described it thus:

In the Philippines, you would worry about your patient if they couldn't afford to buy the medicines. In Libya, they provide for it from admission to discharge. All you have to do is to take care of them. In the Philippines, sometimes you lack the necessary supplies. You would handle patients who couldn't afford to buy medicines. That's a big difference.

When it comes to interactions between the Filipino nurses and their patients, or with their colleagues, however, the positive feelings seem to dissipate. First, with their patients, they had to deal with the rough behavior, sometimes accompanying hostility. They had to deal with irate local patients who they usually describe as "uneducated." There were cases of physical assault: hitting, spitting, and slapping a nurse, and verbal assault: "They are bossy and they like bullying (us)," another interviewee remarked. "They sometimes threaten us," complained one interviewee. Related to this, James clarified why he had difficulty in adjusting to the host country:

They are rude, sarcastic, and bossy. It was hard, but I just had to endure it because I was thinking about my family. I had to earn money, even if they stepped on my dignity.

Another narrative raises issues on gender and religion:

They know that we are foreigners, so they harass us, especially the female nurses because their faces aren't covered. They also knew that they (Filipino female nurses) are not Muslims.... These people (local Libyans) couldn't wait. They could see that the clinic was overcrowded and there were several patients waiting for their turn, but they would knock, open the door and shout. They shout at you because they know that you are a foreigner.

Most of the interviewees also had to contend with the ubiquity of firearms in the country. One interviewee relayed that, according to a local, this proliferation of firearms was caused by Gaddafi's deliberate distribution of firearms in the hope that the people 
would defend him. However this started, the state's inability to monopolize the means of violence, e.g., control of firearms, is a well-known tendency in a post-conflict society. Just how widespread this was could be gleaned from the nurses' frequent encounter with patients, even minors or teenagers, carrying guns inside the medical facility. Worse, some furious patients point their gun to hospital staff when they were distressed or annoyed with the quality of hospital services. While they could cope with the technicalities of their work, Aldrin pointed out how risky the work environment had become due to these firearms:

As regards our work, we already know [how to do it]. The only problem is the attitude of the people in Libya. They are uneducated. And their guns are used like cellphones. They harass us, not only verbally but physically. We were already off-duty, but the armed men would tell us to do something, and they would hurt us if we refuse to work.

Billy has a similar story:

I used to work in the largest hospital of Benghazi. Since it is the largest hospital, all kinds of patients go there for various concerns. But even inside the hospital, we had problems with the violent behavior of the patients. Some of them were drunk. There was a time when a staff was almost stabbed by a patient. Then there were also cases when the patient pointed a gun to a nurse. Worse, when nurses go out of their hospitals, some had experienced being robbed or held-up.

This rough treatment of Filipino nurses, however, is counterbalanced by a high regard for the quality of their service and their skills, compared to the local nurses and other foreigners. Filipino nurses in Libya are well-respected and highly regarded by their colleagues in the industry. All interviewees relayed their pride in being appreciated and recognized for their work by their respective medical institutions. They stressed that hospitals and healthcare institutions-even the patients-throughout the country usually prefer Filipino nurses than local and other foreign nurses. According to Billy, a female nurse, this is because of the reputation of Filipinos as excellent health service providers.

The respondents also reported an expansion of their nursing skills in Libya as the hospital management entrusts them with a wider variety of nursing duties. Moreover, they say that the standard of nursing practice in the Philippines is higher, thus causing more anxiety on the nurses to do their job well, leading one interviewee to compare it to "having Florence Nightingale over your shoulders, ready to call attention to every error that you may commit." Furthermore, hospital nurses in the Philippines are said to be burdened with a lot of paper work.

The narratives so far reveal the labor conditions of Filipino nurses, with their incentives and disincentives. As would be discussed further, these would form part of the considerations in repatriation decisions.

\section{To leave or to stay? Challenges in repatriation}

Increasing violent incidents led the Philippine government to arrange for the repatriation of OFWs. Yet it was not a decision that was easily accepted. An interviewee who 
worked in Sirte claimed that Filipinos in their hospital were even surprised when the Philippine government declared Alert level 4. For them, it was unnecessary to repatriate because there were still pockets of peace, and that the government was just reacting to sporadic violence. Edward described the atmosphere during that time:

We were shocked. What is happening? Why did they raise the alert level? We couldn't feel the need, or even the urge to repatriate at that time. We were all asking, "What's going on?" We knew that violence started in Benghazi, they were containing terrorism, but we were not expecting that announcement. We argued with the people from the embassy and those (embassy officials) in Tripoli - why are you declaring alert level 4? We couldn't even feel that there was something going on. It might be because Binay was there, helping them. So every now and then, there were announcements, but I was intentionally ignoring it.

For those who worked near the affected areas, one of the reasons for staying was the pressure from their superiors and co-workers. Hospital directors coaxed nurses to stay by increasing their salary and promising more benefits. More than this, they were assured of their safety in the hospital, saying that as long as they remain within the premises of the hospital and the protected areas of the locality, they are safe.

Yet the explosions that grew more frequent were gnawing on the repeated assurance of safety. Aldrin, for one, was convinced that their workplace was no longer safe. He recalls his considerations during that time:

We were scared. But of course, we prayed so hard. We were hoping that everything would be normal in Libya, eventually. But the fighting worsened.... Initially, I was undecided to leave because I've been paying for the monthly bills of our house [in the Philippines]. I was thinking that later on, we would be safe and they would release our pay. Also, I was thinking that if it's my time, it would be my time, no matter where I was.

Eventually, however, he joined repatriation because the remittance centers have shut down, and he found it useless to earn a living when there was no way to send the money home.

Other Filipino nurses, particularly those who have reached their 50s, refused to repatriate because, according to Diana:

They would rather transfer to a more peaceful place in Libya than be repatriated.... Some of them have worked there for 35 years or so, and they knew that they won't have any opportunity in the Philippines if they are repatriated. In Libya, even if they reach the retirement age of 60, they can still find job. They can even be employed in three or more jobs. Aside from the fact that they get higher pay, or even double pay for some employees, they were also considering the benefits and gratuity that they will get when they reach the end of the contract. For some, they chose to stay because they haven't saved enough money.

Those who considered repatriation, however, had to contend with another set of risks, both to life and to property. Diana narrated how difficult it was to travel from their place to the nearest airport. It was a dangerous 3-day journey with several stops at 
militia-controlled checkpoints. It may not be endured by their senior colleagues; hence the preference to wait and hope that the situation will get better in time. One of them shared a strategy to ensure that they could still bring some of their earned money to the Philippines:

This is gross. I swallowed my jewelry. And the remaining dollars? I had to hide it from the rebels because they would get it. Believe it or not, I placed it in a condom and I inserted it in my anus. Because wherever you place those things, even inside the car, the rebels get it. But we need to bring money, at least for our travel costs from Manila to our provinces.

The foregoing narratives reveal the nuances of repatriation issue. Far from being just a concern over lost opportunities, it also involves weighing out the associated riskswhere is survival more likely: staying and hoping that the situation gets better eventually or leaving and facing the inevitable encounter with the rebels?

The narratives suggest that most of those who immediately responded to the calls of repatriation were the OFWs near the conflict-affected areas. Other Filipinos, whose workplace and residence were far from the conflict zones, refused to heed the calls for mandatory repatriation. Nelson, for instance, was very firm in his decision to stay in Libya amidst the bombings plaguing their city. He still refused to avail the repatriation program of the Philippine government because, according to him, "poverty can also kill in the Philippines." This part explains why he changed his decision:

If not because of my parents who were crying almost everyday, asking me to come back home, I would have stayed. It was my future I had in mind. I knew that I could take care of myself and I knew how to be safe there. That was also the situation of other Filipino nurses. We wanted to stay because of financial concerns. We thought of repatriation to mean going back to the usual life-applying for work, adjusting to another lifestyle, and life would be hard again.

While the government's persistent calls for emergency repatriation were ignored by several Filipino nurses, the appeal from their parents and family members seemed more persuasive. Edward knew that his parents were emotionally suffering whenever they hear news about the violence in Libya. He narrated:

I don't want them to get worried. I even get mad when they ask me about some news. I asked them to stop watching TV. I knew that I was on denial, but I also knew that the news was partly real, partly fiction. For example, they were showing the fighting episodes at the airport. That doesn't mean the entire country is at war.

When bombings became more frequent, more and more OFWs realized the need to repatriate. The decision to repatriate was also influenced by the incidents of abduction and rape of a Filipino nurse. The news created a chilling effect on Filipino migrant community, breaking illusions of safety, falsifying the belief that Filipinos are safe and insulated from political violence. Charles shared his reason for leaving Libya:

When we heard about the gang rape and the beheading of a Filipino at that particular checkpoint because he said he's a Christian... We were very scared because that was the same spot where we would pass. We heard that there was an unre- 
ported incident about another Filipino who was killed because of the same reason. So we had to pretend that we're Muslims. We memorized a Muslim prayer. We also decided to leave because we heard about several incidents when Libyans ransacked the houses of Filipinos. We realized that we need to leave.

Asked about the prayer they had memorized, Charles shared his experience at the checkpoint:

We memorized the Magrib Prayer. We didn't use it though. But I simply said "Alhamdullilah." After saying those words, I thought they would kill me. They pulled me out of the car, pushed me [to their station], took away my watch, laptop, everything.... When they were satisfied, they released me after one hour. I was very scared. And I was thinking that if I only knew that they would do that, I wouldn't have left the hospital.

Carlo, a nurse from Mizda Al Sheref, explained his reason for joining the repatriation offer of the Philippine government:

At first, we had no problem as we were assured that we're safe. We're far from the airport, anyway, and four hours from the city. Eventually, when the airport, gasoline stations and pipelines were bombed, that was the time when everything has changed. Goods couldn't get in. No more supplies to support the economy of Libya. So the people were robbing the banks and gold deposits. There were no more funds for the salary of the employees. Eventually, we were affected because we didn't receive our salary for more or less 5 months.

Charles and his colleagues decided to stop waiting for their salary. Since remittance centers were no longer operating, they could not send their money to their relatives in the Philippines. They also had problems converting their money to US dollars because the Libyan Dinar, the local currency, may no longer be exchanged outside the country. Thus, money changers took advantage of the situation by exchanging Dinar way below its market rate. Carlo and his colleagues had no choice but to accept the rate to be able to use their earned money outside Libya. Similarly, another narrative describes the worsening scenario in their locality:

Continuous bombing everywhere. No more supply of gasoline, crude, gas, so it was difficult to cook food. We were using electric stove, but they cut the electricity. Even water supply was cut. It was also very expensive to buy charcoal for cooking. We were just looking for wood that can be used for cooking. When winter and rainy season came, we just ate canned foods. There was a point when all of us were coping with the situation by eating bread, sleeping, eating bread, sleeping...

As previously mentioned, hospital directors and managers pressured the Filipino nurses to stay in Libya. In some areas, rebels had started to threaten the hospital workers and urged them to work. Carlo's account reveals their realization during the recurrence of crisis in Libya:

The hospital was no longer safe. They bombed our ambulances and destroyed our offices. We (Filipino nurses) decided to stop working because we were no longer safe, 
to the point that we were wearing bullet proof vest when we go to work. That (not reporting for work) was our way of protesting against the rebels.

For two weeks, we were thinking whether or not to join repatriation. Eventually, we came to a point when we realized that if we stood our ground, we might regret it later.

We decided to go back to work, because we also feared that they would harass or kill us if still refuse to go back to the hospital. We made them realize that we were humble enough, that was our way to neutralize the situation. Later on, half of our group discreetly left. Some of them made it appear that they were just on leave. Then we hired a van that would take us to the Philippine embassy. We didn't mind the cost of the transportation. We left at dawn. Half of the group took the ship, while our group crossed the border to Tunisia.

At time of writing, all the interviewees have already repatriated, with recollections of the difficulty in repatriating, from the risk of going through checkpoints, being robbed, bribing the militias, going hungry and tired at the journey, and finally coming home to face the reality that most of them did not have enough resources to sustain their families. While they are generally thankful to have been supported by the government, some inconveniences were raised, like the process of claiming the Php10,000 included in repatriation package, and the difficulty in converting the Libyan Dinars that they managed to bring home.

\section{Unrealistic optimism: explaining migration behavior in conflict zones}

What have so far been presented were the conditions external to Filipino nurses and the situations that made them repatriate. We know, however, that this decision was not immediate. It took them a while to decide to leave Libya. Of special interest and deserving closer scrutiny is the process of coping while the eventual decision was being deferred. What role did their interpretation or perception to these external conditions play in the decisionmaking? In analyzing this, we do away with the more commonly used theories of migration for the main reason that those do not seem to accord enough attention to migration in conflict areas and turn instead to the risk framework used by Carretero's thesis (2008) in analyzing the behavior of pirogue migrants in the face of high risk migrations. Derived from the works of Mckenna (1993) and Taylor and Armor (1996), Carretero used the concepts of "illusion of control" and "unrealistic optimism" which we also adopted and operationalized in analyzing the case of Filipino nurses in conflict areas. This framework will be juxtaposed with what the narratives reveal about their coping mechanisms and the challenges of arriving at a definite decision after being caught in conflict in Libya.

According to Carretero's thesis, migrants cope with risky and uncertain situations by resorting to an "illusion of control" which could lead to "unrealistic optimism". This unrealistic optimism is behind the risk denial through dismissal of risk information, ignoring precautions, and eventually undertaking risky decisions; in this case, refusing to repatriate. In this section, we highlight the manifestations of "unrealistic optimism", considering the fluidity of risk perceptions as events unfold; i.e., political crisis developed, alert level raised, and repatriation pressure loomed. We argue that this dynamics of unrealistic optimism may meaningfully explain the behavior of Filipino nurses in prolonging their stay, or declining to join the repatriation program. Specifically, this unrealistic optimism 
is evident in their narratives of denial, their accounts of unrealistic hopes, their claims of exceptionality, and their stories of resilience.

When explosions and gunshots became more frequent, the interviewees related their ways of coping, with some admitting denial. Take the case of Billy who described their attitude to bomb threats in the hospital where they worked: "Somehow, we're happy if there are threats because the hospital is closed. We don't have to go to work." In the same breath, she said that even though the Libyans no longer report to work in times like these, the Filipinos still go on duty.

Nelson, for his part, described the experience:

There were times when you would just be surprised that the neighboring house was hit by mortar, but I don't know why Filipinos still report to work even though some already experienced being hit by stray bullets.

After beheadings happened, Edward recalls, "At that moment, it's easy to say that you will stay, even though you know that there was violence outside. Perhaps, in my mind, I was just denying the danger. I just wanted to focus on my upcoming vacation (to the Philippines)". Some narrated coping mechanisms such as not sleeping beside the window of their apartment to avoid being hit by stray bullets, or ignoring the sound of gunshots.

Defying their family members' plea to repatriate, our informants claim that they were safe amidst the continuous bombings in the nearby places. The statement of Nelson saying, "I knew that I could take care of myself and I knew how to be safe there" demonstrates the tendency of distressed migrants to create the "illusion of control," a predisposition that fortifies false beliefs that situation can be measured and controlled by oneself. Similar to the research findings of Carretero (2008), some nurses have created an illusion that they have means of protection in the height of civil war. We have stressed that those are illusory beliefs considering that their narratives also contain accounts of being threatened and ransacked in the hospital.

Unrealistic optimism also manifests in the narratives of "hopes" that situation will be better sooner or later. The interview results reveal that nurses refused to repatriate because they were hoping that bombings will stop, the situation will normalize, and hospitals shall operate on business-as-usual. These unfounded hopes not only decrease their perception of risk, but also provide imagined rewards as they defy uncertainties.

Remarkably, these hopes are also tied with their financial situation. Most of them did not receive their salaries for the last four to 6 months. Hoping that the management would eventually release their salaries, they initially refused to join the repatriation program. Disillusioned by the deeply-ingrained culture of migration in the Philippines, our interviewees expressed embarrassment and humiliation on the probability of homecoming with nothing to give to their families. They also thought that repatriation would end the opportunity of earning a decent salary, despite its delayed release. This would mean their entire family would also suffer when they repatriate, almost tantamount to going back defeated.

Unrealistic optimism is intertwined with the general predisposition that migrants can adjust to the conflict-ridden situation. Respondents claim that even in the middle of bombings, Filipino nurses continued reporting to the hospital. In fact, they were the last ones to abandon their hospital duties. Narratives have also emphasized the Filipino 
migrants' propensity to "get used to it" (bombings). Filipino nurses in their senior years have strongly refused to repatriate not only because of the stress that they would experience during their land travel. Their decision to stay is grounded on their confidence and ability to be resilient.

Risk perception is also entwined to one's identity against the background of their status in the host society. In this study, we noticed the tendency of the respondents to highlight the status of the Filipino nurses as "preferred" or highly regarded health professionals. Local patients, including the members of the militia would need their services. This locus of identification became their pretext to justify that the local Libyans would spare them from their violent activities. Stressing their positive reputation in Libya's healthcare industry, they knew that they are relatively safer than other foreign migrant workers. This sense of confidence, emanating from their ethnic identity as Filipinos, and professional identity as nurses, lessens the perception of risk, thereby sustaining migration amidst the prevailing violence in 2014.

This sense of exceptionality was also fortified by their Libyan supervisors and fellow Filipinos who provide constant assurance that they were safe. According to one interviewee, local nurses and hospital staffs "have done everything they could do to prevent Filipino nurses to leave." To persuade them, they emphasize not only their status as nurses, but also their affiliation and affinity with Libyans. Again, Filipino nurses have realized their exceptionality as compared to other foreign workers because of their personal ties with local Libyans, along with their contributions to the community.

The Philippine government eventually called for mandatory repatriation or Alert level 4. The Department of Foreign Affairs website was regularly updated on information on repatriation, including appeals to the family members in the Philippines to convince the OFWs in Libya to repatriate. The Philippine embassy in Tripoli was likewise disseminating the information through Filipino organizations, groups in social media, and through text messages, announcing the schedule of repatriation and urging them to repatriate while the government can still facilitate it.

It should be noted that during the period of migration, the interaction between the government and the Filipino nurses was limited to online communication and occasional consular visits. Some interviewees have visited the embassy once or twice in order to renew their passports or claim a certain document. Other than consular matters, the embassy has been viewed as a distant institution, both geographically and metaphorically. Moreover, the narratives suggest limited participation of the nurses to migrant organizations and activities organized by the Philippine embassy. Considering the remoteness of their workplaces, it is understandable that Filipino nurses were able to establish their own Filipino community with minimal contact with the embassy tasked to monitor and provide protection and assistance to Filipino nationals in times of distress. While this limited interaction may affect the attitude of Filipino nurses during the height of the crisis, there is not enough indication from the narratives that this level of trust became a major factor in deciding whether or not to repatriate.

Reacting to the repatriation calls of the Philippine government, the interviewees recalled being resistant. The reasons given were that the conflict zones were still far from their workplace, and the Libyan government's security forces were addressing the problem. The Government seemed to them over-reacting, and would rather that the alert 
level be reviewed or lifted. One case was peculiarly informative. Nelson, who, before migration justified his decision to go to Libya despite possible recurrence of conflict, said: "Perhaps the government will not allow us to leave if they know that it's not safe", later on dismissed government advisory as baseless.

Eventually, the sense of security or the illusion of control and optimism was pricked, triggered by the beheading, rape, and kidnapping of Filipinos. The spread of violence closer to their respective workplaces likewise made the dangerous travel from their respective workplaces to the Philippine embassy seemed to be worth the risk. Unrealistic optimism, therefore, has its limits, depending on individual experiences. The timing seems to be relative. For while some already took the risk of repatriation, others sought employment to another place where they think the risk is manageable.

\section{Conclusion}

Through narrative analysis, this paper reveals the contours of nursing migration from the Philippines to the conflict zones of Libya. Filipino nurses took advantage of the massive hiring in 2012 because of the attractive compensation package notwithstanding the lenient and rapid hiring procedures. Libya was their "transit point" (see Carlos 2013), a stepping stone in preparation for their plan to migrate to a more preferred destination.

A more intriguing inquiry was the dynamics that sustained migration during the height of the conflict in 2014. Defiance to the government-imposed repatriation raised questions of how migrants made sense of their action and inaction against the backdrop of worsening danger and vulnerability. From the lens of risk perception, we examined how risks and uncertainties were given meanings, and how these interpretations of risks prevent them from availing the Philippine government's mandated repatriation. We argue that these Filipino nurses have exhibited "unrealistic optimism" as risk minimizing strategy, thereby diminishing the sense of urgency to repatriate in the midst of a worsening conflict scenario. Because of this predisposition, our respondents claim that they participated in the repatriation program for their families' sake and not directly because of their individual safety.

Unrealistic optimism may not only be attributed to the psycho-social stress experienced during the conflict period. As clearly manifested in the narratives, it was cultivated by pre-migration perceptions and migration culture, furthered by the positive and negative experiences of migration in Libya. Highlighting their resiliency, Filipino nurses claim to have adjusted to their environment where bombings and ricocheting machine guns were part of their daily encounters. They have reinterpreted the value of risks, and eventually denied the reality of danger.

On the policy level, it is acknowledged that the capacity of embassies in terms of human and financial resources, compounded by the relative difficulty of negotiations in cases where the host government has no effective control and legitimacy will make it difficult to ensure that the ideal conditions in repatriating OFWs will be done. This notwithstanding, some options may be considered.

Evidences of unrealistic optimism calls for a better way of delivering the message for repatriation in a way that takes into account the fact that there exists violence-free area where Alert Level 4, for instance, does not seem to make sense to OFWs. Messaging could be framed in such a way that includes an analysis of what may happen. This allows 
them to realize that the relative peace being experienced in their area is temporary. For OFWs whose access to such analysis/forecast is very limited, this could be particularly helpful in weighing out their options.

While this research pushed the inquiry beyond the usual understanding that the overwhelming consideration for repatriation from a conflict zone is financial, exploring options for easing the financial concerns will be a welcome development and one less thing for the OFWs to consider when deciding to repatriate. A government-managed insurance policy for OFWs that cushions them in case of mandatory repatriation can help in avoiding situations where the only thing they can hold onto is the money that they can bring home or a P10,000.00 cash included in the repatriation package-in the worst case scenario that they were not able to save. There also surfaced a concern that terminating their contract due to repatriation will affect future employment opportunities. A certification from OWWA that the termination of contract was from an emergency repatriation which was beyond the control of the person who repatriated may be issued.

Finally, while the government views the repatriation program from Libya as a successful case because of the proactive participation and cooperation of migrant organizations, the narratives indicate that some Filipino nurses are disconnected from these groups. Diplomatic missions should further intensify their coordination with migrant organizations. The government, through pre-departure orientation and consular visits, should also encourage Filipino migrants to be involved with affiliated groups that support the plights of OFWs.

These policy recommendations are by no mean exhaustive, but are meant to catalyze a discussion on how emergency repatriation could be designed based on the examination of perceptions on opportunities and risks during pre-migration, the incentives and disincentives during their stay, and the repatriation challenges that this exploratory research has shed light on.

Authors' contributions

Both authors conceptualized the research design, analyzed the data, and wrote the manuscript. Both authors read and approved the final manuscript.

Author details

${ }^{1}$ International Studies Department, De La Salle University-Manila, Manila, Philippines. ${ }^{2}$ Department of Finance, Philippines-Italy Debt for Development Swap Program, Manila, Philippines.

\section{Acknowledgements}

The authors wish to acknowledge Darren Mangado for providing assistance in gathering materials and conducting interviews.

Compliance with ethical guidelines

Competing interests

The authors declare that they do not have competing interests.

Received: 23 July 2015 Accepted: 31 August 2015

Published online: 10 September 2015

\section{References}

Abuhadra, Dia Sadek and Tawfik Taher Ajaali. 2014. Labour market and employment policy in Libya. European Training Foundation. Accessed 10 May 2015. http://www.etf.europa.eu/webatt.nsf/0/01BE9A2F283BC6B2C1257D1E0041161 A/\$file/Employment\%20policies_Libya.pdf.

Arends-Kuenning, Mary, Alvaro Calara, and Stella Go. 2015. International migration opportunities and occupational choice: a case study of Filipino nurses 2002 to 2014. IZA Discussion Paper 8881. Forschungsinstitut zur Zukunft de Arbeit Institute for the Study of Labor. 
Asis, Maruja. 2002. From the life stories of Filipino women: personal and family agendas in migration. Asian and Pacific Migration Journal 11:67-93.

Asis, Maruja, and Fabio Baggio. 2008. Introduction: Will turning transnational foster development in the Philippines? In Moving out, back and up: International migration and development prospects in the Philippines, ed. Maruja Asis, and Fabio Baggio, 1-16. Quezon City: Scalabrini Migration Center.

Ball, Rochelle. 2004. Divergent development, racialized rights: globalized labour markets and the trade of nurses: the case of the Philippines. Women's Studies International Forum 27: 119-133.

Ball, Rochelle, and Nicola Piper. 2002. Globalisation and regulation of citizenship: Filipino migrant workers in Japan. Political Geography 21: 1013-1034.

Basa, Charito. 2008. Remittances, migration, and development: Perspectives of Filipino migrants in Italy. In Moving out, back and up: International migration and development prospects in the Philippines, ed. Maruja Asis, and Fabio Baggio, 1-16. Quezon City: Scalabrini Migration Center.

Battistella, Graziano. 2012. Multi-level policy in the governance of labor migration: Considerations from the Philippine experience. Asian Journal of Social Science 40(4): 419-446.

Carlos, Maria Reinaruth. 2013. The stepwise international migration of Filipino nurses and its policy implication for their retention in Japan. Studies on Multicultural Societies. Accessed 10 May 2015. http://afrasia.ryukoku.ac.jp/english/ publication/upfile/Working\%20Paper23.pdf.

Carlos, Maria Reinaruth, and Chizuko Sato. 2008. Sending society's responses to international migration of nurses and its policy implications: the case of the Philippines. Ritsumeikan International Affairs 6: 27-51.

Carretero, Maria Hernandez. 2008. Risk-taking in unauthorised migration. Masters Thesis, University of Tromso. Accessed 10 May 2015. http://munin.uit.no/bitstream/handle/10037/1577/thesis.pdf? sequence=1.

Castles, Stephen, and Mark Miller. 2009. The age of migration: International population movements in the modern world. New York: Palgrave Macmillan.

Choy, Catherine Ceniza. 2003. Empire of care: Nursing and migration in Filipino American history. Durham: Duke University Press.

David, Randolf. 1991. Filipino workers in Japan: vulnerability and survival. Kasarinlan 6: 9-23.

Duaqui, Yellowbelle. 2013. From Marcos to Aquino governments: state sponsorship of diaspora philanthropy. Philippine Social Science Review 65(2): 73-99.

Fresnoza-Flot, Asuncion. 2009. Migration status and transnational mothering: the case of Filipino migrants in France. Global Networks 9: 252-270.

GMA News. 2015. More Pinoys set to arrive home from Syria, Lybia. Accessed 10 May 2015. http://www.gmanetwork. com/news/story/481214/pinoyabroad/news/more-pinoys-set-to-arrive-home-from-syria-libya.

Hamood, Sara. 2006. African transit migration through Libya to Europe: The human cost. The American University in Cairo, Forced Migration and Refugee Studies. Accessed 10 May 2015. http://www.migreurop.org/IMG/pdf/hamoodlibya.pdf.

IOM Country Migration Report. 2013. The Philippines. Makati City: International Organization for Migration.

Espiritu, Yen. 2003. Homebound: Filipino American lives across cultures, communities, and countries. Los Angeles: University of California Press.

Lorenzo, Fely Marilyn, Jaime Galvez-Tan, Kriselle Icamina, and Lara Javier. 2007. Nurse migration from a source country perspective: philippine country case study. Health Services Research 42: 1406-1408.

McKenna, Frank P. 1993. It won't happen to me: Unrealistic optimism or illusion of control? British Journal of Psychology 84(1): 39-50.

McKenzie, David, Caroline Theoharides, and Dean Yang. 2014. Distortions in the International Migrant Labor Market: evidence from Filipino Migration and Wage Responses to Destination Country Economic Shocks. American Economic Journal: Applied Economics 6(2): 1-29.

Migration Policy Center Team. 2013. MPC migration profile: Libya.

Philippine Commission on Women. 2014. Women's Empowerment, Development, and Gender Equality Plan, 2013-2014. Accessed 30 August 2014. http://library.pcw.gov.ph/sites/default/files/WEDGE_plan_2013-2016_0.pdf.

Rodriguez, Robyn. 2002. Migrant heroes: nationalism, citizenship and the politics of Filipino migrant labor. Citizenship Studies 6: 341-356.

Rodriguez, Robyn. 2010. Migrants for export: How the Philippine state brokers labor to the world. Minneapolis: University of Minnesota Press.

Santos, Matikas. 2014. Many OFWs from Libya backing out from repatriation: DFA. Philippine Daily Inquirer. Accessed 10 May 2015. http://globalnation.inquirer.net/109378/many-ofws-in-libya-backing-out-from-repatriation-dfa.

San Juan, E. Jr. 2001. The Filipino diaspora. Philippine Studies 49(2): 255-264.

Semyonov, Mosche, and Anastasia Gorodseisky. 2005. Labor migration, remittances and household income: a comparison between Filipino and Filipina overseas workers. International Migration Review 39: 45-68.

Stasiulis, Daiva, and Abigail Bakan. 1997. Regulation and resistance: strategies of migrant domestic workers in Canada and internationally. Asian and Pacific Migration Journal 6: 31-57.

Tacoli, Cecilia. 1999. 6. Migrating 'for the sake of the family'? Gender, life course, and infra-household relations among Filipino migrants in Rome. Philippine Sociological Review 44: 12-32.

Taylor, Shelley and David Armor. 1996. Positive illusions and coping with adversity. Journal of Personality 64(4): 873-898. 